О.В. Іванько', В.В. Скиба'ㄹ, Аль-Ламі Саад Хамуд Хассан ${ }^{2}$, А. В. Гоман"2, В.В. Лисиця' ${ }^{1}$ Комунальне некомерційне підприємство «Київська міська клінічна лікарня № 1"

${ }^{2}$ Київський медичний університет

\title{
Порівняльна ефективність застосування апаратно-контрольованої коагуляції та традиційного методу в оперативному лікуванні пацієнтів із гемороєм 3-ї та 4-ї стадії
}

Мета - порівняти клінічні результати гемороїдектомії за допомогою електрокоагуляційного гемостатичного пристрою LigaSure ${ }^{\text {TM }}$ (ЕКГП) та традиційного методу за Мілліганом - Морганом. Об'єкт і методи дослідження. У дослідження були включені 182 пацієнти обох статей віком 16-80 років з гемороєм 3-ї та 4-ї стадії, яким проведена гемороїдектомія: 78 - за допомогою ЕКГП, 104 - традиційним методом. Ретроспективно проаналізовані дані про пацієнтів: стать, вік, перед- та післяопераційний рівень гемоглобіну та гематокриту, тривалість операції, наявність тромбозу, кількість видалених та залишених вузлів, кількість ліжко-днів, ранні та пізні післяопераційні ускладнення, потреба в наркотичних знеболювальних засобах, період спостереження та час до повернення до нормальної щоденної активності. Результати. Тривалість операції становила 16 (5-60) хв у групі ЕКГП та 22 (6-40) хв - у групі традиційного методу. Анальгетики у післяопераційному періоді застосовували у 82 (78,8\%) осіб групи традиційного лікування та у 29(37,2\%) - у групі ЕКГП. Необхідний час для повернення до нормальної щоденної активності становив 6(1-15) днів у групі ЕКГП і 7(1-30) - традиційного методу. Висновки. Встановлено, що ЕКГП перевершує традиційний метод за тривалістю операції, періодом госпіталізації, післяопераційними потребами узнеболенні, ризиком післяопераційних кровотеч та часом, необхідним для повернення до нормальної повсякденної активності.

Ключові слова: геморой, гемороїдектомія, LigaSure ${ }^{T M}$, гемороїдектомія за Міліганом - Морганом.

\section{Вступ}

Геморой - це підслизові утворення, що включають венули, артеріоли та гладком'язові волокна, розміщені в анальному каналі. Гемороїдальну хворобу діагностують приблизно у $5 \%$ людей загальної популяції, особливо у віці $>40$ років (Cohen Z., 1985; Arslani N. et al., 2012). Лікування геморою показане лише у симптоматичних випадках. Ці симптоми включають кровотечу, тромбоз та випадіння гемороїдальних вузлів (Bullard K.M., Rothenberg D.A., 2005). При лікуванні геморою використовують різні методи - медичне лікування, накладання гумових кілець, інфрачервону фотокоагуляцію, склеротерапію, відкриту та закриту гемороїдектомію, гемороїдектомію за Уайтхедом та степлерну гемороїдектомію.

Консервативне лікування зазвичай ефективне при геморої 1-ї та 2-ї стадії, проте гемороїдальні вузли 3-ї та 4-ї стадії потребують хірургічного втручання. Існують два добре відомі хірургічні способи гемороїдектомії: відкритий (Milligan E.T.C. et al., 1937) та закритий (Ferguson J.A., Heaton J.R., 1959). Ці методи мають подібні ускладнення, такі як післяопераційна кровотеча та післяопераційний біль. Тривалість госпіталізації та час до повернення до роботи чи звичайних повсякденних справ подібні (Ho Y.H. et al., 2000). Гемороїдектомія за допомогою LigaSure ${ }^{\mathrm{TM}}$ («Medtronic plc», Ірландія) - альтернатива відкритій гемороїдектомії при лікуванні геморою 3-ї та 4-ї стадії (Khanna R. et al., 2010). LigaSure ${ }^{\mathrm{TM}}$ - електрокоагуляційний гемостатичний пристрій (ЕКГП), який лігує судини шляхом оптимізованої комбінації радіочастотної абляції та стискання браншами (Kennedy J.S. et al., 1998). ЕКГП забезпечує повну лігацію артерій і вен діаметром до 7 мм. Цей метод має низку переваг: простота в освоєнні, швидкість процедури, контроль кровотечі, мінімальне пошкодження тканин, незначний післяопераційний біль і короткий час до повернення до нормальної щоденної активності (Mastakov M.Y. et al., 2008; Nienhuijs S. de Hingh I., 2009; Milito G. et al., 2010).
Мета - порівняти клінічні результати гемороїдектомії за допомогою ЕКГП та традиційного методу за Мілліганом - Морганом.

\section{Об"єкт і методи дослідження}

У дослідження включені 182 пацієнти обох статей віком 16-80 років з гемороєм 3-ї і 4-ї стадії, яким на базі Комунального некомерційного підприємства «Київська міська клінічна лікарня № 1» у період січень 2014-січень 2020 рр. проведено гемороїдектомію за допомогою ЕКГП ( $n=78$; основна група) або за традиційним методом (n=104; контрольна група).

Пацієнтів з цирозом печінки, періанальними захворюваннями, запальними захворюваннями кишечнику, коагулопатією та вагітних не включали у дослідження.

Колоноскопію проводили всім пацієнтам віком $>50$ років для виключення раку товстої кишки. Лікування антикоагулянтами або ацетилсаліциловою кислотою припиняли за 5 днів до лікування.

Усі пацієнти перед операцією підписали інформовану згоду на втручання.

Пацієнти перенесли операцію під загальною чи спинномозковою анестезією в літотомічній позиції. В основній групі судинну ніжку гемороїдального вузла обробляли за допомогою ЕКГП, дефект слизової оболонки після видалення вузла залишався відкритим. У контрольній групі вузли висікали електрокаутером, при цьому ніжку вузла прошивали, дефект слизової оболонки також залишався відкритим.

Дані про пацієнтів вивчали ретроспективно шляхом аналізу історій хвороб та телефонного опитування. У післяопераційний період (7-ма доба) у оперованих аналізували такі показники: стать, вік, передопераційний та післяопераційний рівень гемоглобіну та гематокриту, тривалість операції, наявність тромбозу, кількість видалених та залишених вузлів (що не видаляли у зв'язку з ризиком анального стенозу у пацієнтів із наявністю >3-х вузлів), кількість ліжко-днів, ранні та пізні післяопераційні ускладнення, наявність тривалого болю та потреба у наркотичних знеболювальних 
засобах, період спостереження та час до повернення до нормальної щоденної активності/роботи. Наркотичні анальгетики для післяопераційного знеболення призначали лише при вираженому болю та недостатнього ефекту нестероїдних протизапальних препаратів. Пацієнтам телефонували і запитували щодо наявності болю протягом 30 днів після операції.

Дані аналізували за допомогою статистичного пакета «SPSS Version 20.0 for Windows» («IBM», США). Результати вказані як відсотки, середні та стандартні відхилення, або медіана та діапазон. Кількісні змінні порівнювали за допомогою t-критерію Стьюдента або U-критерію Манна - Уїтні, якісні змінні порівнювали за допомогою критерію $\chi^{2}$. Значення $\mathrm{p}<0,05$ вважали достовірним.

\section{Результати та їх обговорення}

Передопераційні рівні гемоглобіну та гематокриту становили $13,3 \pm 1,5$ г/дл та $38,9 \pm 5,5 \%$ у групі контролю та 13,2 11,9 г/дл та $39,5 \pm 5,1 \%-$ в основній групі. Показники на 7-й день після операції суттєво не відрізнялись від початкових рівнів і становили $13,0 \pm 1,7$ г/дл та $39,3 \pm 5,1 \%$ та $13,2 \pm 1,9$ г/дл та $39,5 \pm 5,1 \%$ відповідно (табл. 1).

Таблиця 1. Загальні характеристики пацієнтів

\begin{tabular}{lccc}
\hline \multicolumn{1}{c}{ Показник } & \multicolumn{2}{c}{ Група } & \multirow{2}{*}{ p } \\
\cline { 2 - 3 } & Контрольна & 0сновна & 0,712 \\
Кількість пацієнтів, $n$ & 104 & 78 & 0,712 \\
Середній вік, років & 41 & 40 & 0,615 \\
Передопераційний рівень гемоглобіну, г/дл & $13,3 \pm 1,5$ & $13,2 \pm 1,9$ & 0,31 \\
Передопераційний рівень гематокриту, \% & $38,9 \pm 5,5$ & $39,5 \pm 5,1$ & 0,37 \\
$\begin{array}{l}\text { Післяопераційний рівень гемоглобіну } \\
\text { (7-й день), г/дл }\end{array}$ & $13,0 \pm 1,7$ & $13,2 \pm 1,9$ & 0,40 \\
$\begin{array}{l}\text { Післяопераційний рівень гематокриту } \\
\text { (7-й день), \% }\end{array}$ & $39,3 \pm 5,1$ & $39,5 \pm 5,1$ & 0,60 \\
\hline
\end{tabular}

Кількість вузлів, оброблених хірургічним шляхом, була подібною у групах. Тривалість операції становила 16 (5-60) хв в основній та 22 (6-40) хв - у контрольній групі (табл. 2).

Таблиця 2. Особливості методу ЕКГП і традиційної методики

\begin{tabular}{|c|c|c|c|}
\hline \multirow[b]{2}{*}{ Показник } & \multicolumn{2}{|c|}{ Група } & \multirow[b]{2}{*}{$\mathbf{p}$} \\
\hline & Контрольна & Основна & \\
\hline Тривалість операції, хв & $22(6-40)$ & $16(5-60)$ & $<0,05$ \\
\hline Потреба у наркотичних анальгетиках, n (\%) & $82(78,8)$ & $29(37,2)$ & $<0,05$ \\
\hline Час госпіталізації, днів & $2(1-3)$ & $1(0,5-1,5)$ & $<0,05$ \\
\hline Повторна операція, n (\%) & $2(2,0)$ & $2(2,6)$ & 0,804 \\
\hline $\begin{array}{l}\text { Повернення до нормальної щоденної } \\
\text { активності, днів }\end{array}$ & $7(1-30)$ & $6(1-15)$ & $<0,05$ \\
\hline Тривалий біль, n (\%) & $13(12,5)$ & $5(6,4)$ & $<0,05$ \\
\hline
\end{tabular}

Усі хворі після операції отримували нестероїдні протизапальні препарати. У разі їх недостатнього ефекту призначали наркотичні анальгетики: 82 (78,8\%) хворим контрольної та 29 (37,2\%)основної групи $(p<0,05)$. Тромбоз спостерігали у $5(4,8 \%)$ пацієнтів контрольної та $6(7,7 \%)$ - основної групи $(p=0,195)$. Повторна операція у зв'язку з кровотечею знадобилася $2(2,0 \%)$ пацієнтам контрольної та 2 (2,6\%) - основної групи. В одному випадку у контрольній групі знадобилася повторна операція у зв'язку з некрозом слизової оболонки анального каналу. Усіх пацієнтів після повторних операцій виписано у задовільному стані.

Середній час госпіталізації становив 1 день в основній та 2 в контрольній групі, час повернення до нормальної щоденної активності -6 та 7 днів відповідно $(p<0,05)$. Пацієнтів опитували про наявність болю в перші 30 днів після гемороїдектомії. $5(6,4 \%)$ хворих з основної та 13(12,5\%) - з контрольної групи зазначали, що відчували суттєвий біль (див. табл. 2).

У перші 7 днів кровотеча зареєстрована у 15 випадках, з них 12 операцій проведено традиційним методом у 3 - задопомогою ЕКГП $(p<0,05)$. Одному хворому з контрольної групи та одному з основної зробили повторні операції з приводу кровотечі. В інших випадках кровотеча спонтанно припинилася. В одному випадку в основній групі повідомляли про періанальний набряк, який спонтанно розсмоктався. Залишкові вузли визначали у 5 $(4,8 \%)$ випадках у контрольній та у $3(3,8 \%)-$ основній групі $(p=0,370)$. Нетримання газів відзначали у 2 осіб контрольної та в 1 - основної групи $(\mathrm{p}=0,220)$. Про анальний стеноз повідомлено в одному випадку у контрольній та у двох - основній групі. Цих хворих проліковано шляхом анальної дилатації без будь-яких подальших ускладнень (табл. 3).
Таблиця 3. Характеристика ускладнень

\begin{tabular}{lccc}
\hline \multicolumn{1}{c}{ Показник } & \multicolumn{2}{c}{ Група } & \multirow{2}{*}{$\mathbf{p}$} \\
\cline { 2 - 3 } & Контрольна & Основна & \\
\hline Кровотеча, $\mathrm{n}(\%)$ & $12(11,5)$ & $3(3,8)$ & $<0,05$ \\
Залишкові вузли, $\mathrm{n}(\%)$ & $5(4,8)$ & $3(3,8)$ & 0,370 \\
Анальний стен03, $\mathrm{n}(\%)$ & $1(0,9)$ & $2(2,6)$ & 0,142 \\
Нетримання газів, $\mathrm{n}(\%)$ & $2(1,92)$ & $1(1,3)$ & 0,220 \\
\hline
\end{tabular}

Традиційні методи хірургічного лікування геморою 3-ї та 4-ї стадії застосовують понад половини століття (Khanna R., et al., 2010). Метод ЕКГП використовують при гемороїдектомії, що коагулює судини діаметром до 7 мм, з термічним ураженням сусідньої тканини до 2 мм. Ця перевага дозволяє швидко коагулювати та відсікати гемороїдальні вузли без кровотечі. Порівняльні дослідження ЕКГП зі звичайними методами можна знайти в літературі (Khanna R. et al., 2010; Peker K. et al., 2013). Згідно з дослідженням K. Peker та співавторів (2013) у групі ЕКГП тривалість операції та час повернення до роботи були коротшими, ніж у звичайній групі, в той час як період госпіталізації та ускладнення були подібними. У метааналізі M.Y. Mastakov та співавторів (2008) у 11 дослідженнях за участю 1046 пацієнтів, у осіб, які перенесли операцію за допомогою ЕКГП, майже всі показники були кращими, ніж у звичайній групі, за винятком ускладнень. У багатьох дослідженнях (Mastakov M.Y. et al., 2008) повідомлялося, що післяопераційні потреби в знеболювальних засобахбули статистично достовірно меншими угрупі ЕКГП. Подібним чином у проведеному нами дослідженні післяопераційні наркотичні знеболювальні засоби були необхідні значно рідше у групі ЕКГП $29(37,2 \%)$ та $82(78,8 \%)$ відповідно. Вважається, що ця суттєва різниця зумовлена наявністю прошивних лігатур на судинній ніжці, що використовують в традиційній методиці.

У багатьох дослідженнях визначали, що час операції значно коротший при гемороїдектомії за допомогою ЕКГП: 12,5 та 29 (Khanna R. et al., 2010), 22,3 та 27,4 (Gentile M. et al., 2011) та 9,4 та 18,2 хв відповідно (Tan K.Y. et al., 2008). Аналогічно у проведеномунами дослідженні з застосуванням ЕКГП час операції був значно меншим, ніж при традиційній методиці (16 та 22 хв відповідно).

У дослідженні R. Khanna та співавторів (2010) період госпіталізації після операції був значно коротшим у групі ЕКГП (1,4 та 3,2 дня відповідно). Однак у дослідженні M. Gentile та співавторів (2011) періоди госпіталізації $24 \pm 2$ год були однаковими удвохгрупах. У проведеному нами дослідженні середній період госпіталізації становив 1 день в основній та 2 - у контрольній групі. Це можна пояснити тим, що хворі, яким застосовували традиційну методику, мали більш виражений больовий синдром та були залишені в клініці.

Швидке загоєння місця пошкодження прискорює нормалізацію щоденної активності. Пацієнти, які перенесли операцію з ЕКГП, повернулися до звичайної повсякденної діяльності за коротший час, ніж пацієнти контрольної групи (6 та 7 днів відповідно). Y.C. Chung, H.J. Wu (2003) не повідомили про різницю в цих параметрах. G. Milito та співавтори (2010) та J. Sayfan та співавтори (2001) відзначили коротші періоди повернення до звичної повсякденної діяльності у групі ЕКГП (7,4 та 18,6 дня відповідно).

Післяопераційну кровотечу при застосуванні ЕКГП у проведеному нами дослідженні спостерігали у $3,8 \%$, при традиційній методиці - у $11,5 \%$ випадках, у дослідженні R. Khanna та співавторів (2010) - у 3,5 та 10,0\% відповідно. Частота залишкового геморою у вищезгаданому дослідженні була нижчою у групі ЕКГП (3,5 та 5\% відповідно); так само у проведеному нами дослідженні цей показник був нижчим у групі ЕКГП (3,8 та 4,8\% відповідно). Однак, як в літературі, так і в проведеному нами дослідженні, ці відмінності не були статистично значущі.

Розвиток анального стенозу внаслідок термічного пошкодження при використанні ЕКГП описано в багатьох дослідженнях. V. Filingeri та співавтори (2004) повідомили про анальний стеноз у 4 із 203 пацієнтів, в яких застосовували ЕКГП, M. Gentile та співавтори (2011) описують 1 випадок із 25 пацієнтів. У проведеному нами дослідженні частка розвитку анального стенозу була подібною до даних літератури (2,6\%). Ключовим моментом для запобігання розвитку анального стенозу є збереження достатньої кількості слизової оболонки в проміжках між видаленими вузлами, так званих містках, та анодермі.

\section{Висновки}

Це ретроспективне дослідження демонструє переваги застосування методу ЕКГП порівняно з традиційним методом опе- 
ративного лікування пацієнтів із гемороєм 3-ї та 4-ї стадії. Встановлено, що методика ЕКГП перевершує звичайний метод щодо тривалості операції, періоду госпіталізації, післяопераційної потреби у знеболювальних засобах, частоти післяопераційних кровотеч та часу повернення до звичайної щоденної активності.

\section{Список використаної літератури}

Arslani N., Patrlj L., Rajkovic Z. et al. (2012) A randomized clinical trial comparing Ligasure versus stapled hemorrhoidectomy. Surg. Laparosc. Endosc. Percutan. Tech., 22(1): 58-61.

Bullard K.M., Rothenberg D.A. (2005) Colon, Rectum, and Anus. In: Brunicard F.C. (Ed.) Swhwartz's Principles of Surgery. 8th edn. McGraw Hill, New York, p. 1055-1117.

Chung Y.C., Wu H.J. (2003) Clinical Experience of Sutureless Closed Hemorrhoidectomy with Ligasure. Dis. Colon. Rectum., 46: 87-92.

Cohen Z. (1985) Symposium on outpatient anorectal procedures. Alternatives to surgical hemorrhoidectomy. Can. J. Surg., 28: 230-231.

Ferguson J.A., Heaton J.R. (1959) Closed hemorrhoidectomy. Dis. Colon. Rectum., 2: 176-179.

Filingeri V., Gravante G., Baldessari E. et al. (2004) Prospective randomized trial of submucosal hemorrhoidectomy with radiofrequency bistouryvs. conventional Parks' operation. Techniq. Coloproctol., 8: 31-36.

Gentile M., De Rosa M., Carbone G. et al. (2011) Ligasure Haemorrhoidectomy versus Conventional Diathermy for IV-Degree Haemorrhoids: Is It the Treatment of Choise? A Randomized, Clinical Trial. ISRN Gastroenterology.

Ho Y.H., Cheong W.K., Tsang C. et al. (2000) Stapled hemorrhoidectomy-cost and effectiveness. Randomized, controlled trial including incontinence scoring, anorecta manometry, and endoanal ultrasound assessments at up to three months. Dis. Colon. Rectum., 43: 1666-1675.

Kennedy J.S., Stranahan P.L., Taylor K.D., Chandler J.G. (1998) High-burst strength, feedback controlled bipolar vessel sealing. Surg. Endosc., 12: 876-878.

Khanna R., Khanna S., Bhadani S. et al. (2010) Comparison of Ligasure Hemorrhoidectomy with Conventional Ferguson's Hemorrhoidectomy. Indian. J. Surg., 72 294-297.

Mastakov M.Y., Buettner P.G., Ho Y.H. (2008) Updated meta-analysis of randomized controlled trials comparing conventional excisional haemorrhoidectomy with Ligasure for haemorrhoids. Tech. Coloproctol., 12: 229-239.

Milito G., Cadeddu F., Muzi M.G. et al. (2010) Haemorrhoidectomy with Ligasure vs conventional excisional techniques: meta-analysis of randomized controlled trials Colorectal. Dis., 12: 85-93.

Milligan E.T.C., Naunton Morgan C., Jones L., Officer R. (1937) Surgica anatomy of the anal canal, and the operative treatment of hemorrhoids. Lancet, 230 $1119-1124$.

Nienhuijs S., de Hingh I. (2009) Conventional versus Ligasure hemorrhoidectomy for patients with symptomatic Hemorrhoids. Cochrane Database Syst. Rev., 21: CD006761.

Peker K., Inal A., Güllü H. et al. (2013) Comparison of Vessel Sealing Systems with Conventional. Iranian. Red. Crescent. Med. J., 15: 488-496.

Sayfan J., Becker A., Koltun L. (2001) Sutureless closed hemorrhoidectomy: a new technique. Ann. Surg., 234: 21-24.

Tan K.Y., Zin T., Sim H.L. et al. (2008) Randomized clinical trial comparing LigaSure haemorrhoidectomy with open diathermyhaemorrhoidectomy. Tech. Coloproctol., 12 93-97.

\section{Сравнительная эффективность аппаратно-контролируемой коагуляции и традиционного метода оперативного лечения пациентов с геморроем 3-й и 4-й стадии}

\section{А.В. Иванько, В.В. Скиба, Аль-Лами Саад Хамуд Хассан, А.В. Гоман, В.В. Лисица}

Резюме. Цель - сравнить клинические результаты геморроидэкто мии с помощью электрокоагуляционного гемостатического устрой- ства LigaSure ${ }^{T M}$ (ЭКГУ) и традиционного способа по Миллигану Моргану. Объект и методы исследования. В исследование были включены 182 пациента обоих полов в возрасте 16-80 лет с геморроем 3-й и 4-й стадии, которым проведена геморроидэктомия: 78 с помощью ЭКГУ, 104 - традиционным способом. Ретроспективно проанализированыданные о пациентах: пол, возраст, пред-и послеоперационный уровень гемоглобина и гематокрита, длительность операции, наличие тромбоза, количество удаленных и оставленных узлов, количество койко-дней, ранние ипоздние послеоперационные осложнения, потребность в наркотических обезболивающих средствах, период наблюдения и время до возвращения к нормальной повседневной активности. Результаты. Длительность операции составила 16 (5-60) мин в группе ЭКГУ и 22 (6-40) мин - в группе традиционного способа. Анальгетики в послеоперационный период применяли у 82 (78,8\%) пациентов группы традиционного лечения и у29(37,2\%) - вгруппе ЭКГУ. Необходимое время для возвращения к нормальной ежедневной активности составило 6 (1-15) дней в группе ЭКГУ и 7 (1-30) - в группе традиционного метода. Выводы. Установлено, что ЭКГУ превосходит традиционный метод по таким показателям, как продолжительность операции, период госпитализации, послеоперационная потребность в обезболивании, послеоперационные кровотечения и время, необходимое для возвращения к нормальной повседневной активности.

Ключевые слова: геморрой, геморроидэктомия, LigaSure ${ }^{T M}$, геморроидэктомия по Милигану - Моргану

\section{Comparative efficiency of apparatus- controlled coagulation and traditional method of surgical treatment in patients with grade III and IV hemorrhoids \\ A.V. Ivanko, V.V. Skiba, Al-Lami Saad Hamud Hassan, A.V. Goman, V.V. Lysytsya}

Summary. The aim is to compare the clinical results of electrocoagulation hemostatic device LigaSure ${ }^{T M}$ (ECHD) hemorrhoidectomy and Milligan Morgan hemorrhoidectomy. Object and methods of research. This study included 182 patients both sexes aged 16-80 with grade III and IV hemorrhoids who underwent hemorrhoidectomy with $\operatorname{ECHD~(~} n=78)$ or conventional method ( $n=104)$. Patients were retrospectively analyzed: gender, age, pre- and postoperative hemoglobin and hematocrit level, duration of surgery, presence of thrombosis, number of removed and left nodes, number of bed-days, early and late postoperative complications, need for narcotic analgesics, follow-up period and time to return to normal daily activities. Results. The operation time was 16(5-60) min in the ECHD and 22 (6-40) - in the conventional method group. Postoperative analgesics were used in $82(78.8 \%)$ cases in the conventional treatment and in $29(37.2 \%)$ cases in the ECHD group. The time required to return to normal daily activity was $6(1-15)$ days in the ECHD and $7(1-30)$ days in the conventional method group. Conclusions. The study found that ECHD outperformed the conventional method in duration of surgery, period of hospitalization, postoperative pain relief needs, postoperative bleeding as well as the time required to return to normal daily activity.

Key words: hemorrhoids, hemorrhoidectomy, LigaSure ${ }^{T M}$, Milligan Morgan hemorrhoidectomy.

Адреса для листування

Гоман Андрій В'ячеславович

02000, м. Київ, вул. Бориспільська, 2

Київський медичний університет, кафедра хірургічних хвороб № 1

E-mail: angoman10281@gmail.com

Получено 21.09.2020 